\title{
A new species of Demidospermus (Platyhelminthes, Monogenea, Ancyrocephalidae) from the catfish Parapimelodus valenciennis in Samborombón Bay, Argentina
}

\author{
Marcotegui Paula S. ${ }^{*}$ and Martorelli Sergio R. \\ CEPAVE (CCT - CONICET - LA PLATA) (FCNyM-UNLP), 2 No. 584, La Plata, Buenos Aires, CP 1900, Argentina
}

\begin{abstract}
Demidospermus annulus sp. nov. (Platyhelminthes, Monogenea, Ancyrocephalidae) is described from the gills of the catfish Parapimelodus valenciennis Lütken collected in Samborombón Bay, Argentina. The new species differs from all congeneric species mainly by the structure of the accessory piece of the male copulatory organ, the sclerotized ring-shaped vaginal aperture and the dorsal bar articulation.
\end{abstract}

\section{Keywords}

Monogenea, Demidospermus, catfish, Salado River, western Atlantic coast

\section{Introduction}

Currently, there are 20 nominal species of Demidospermus (Platyhelminthes, Monogenea, Ancyrocephalidae) parasitizing siluriform fishes from South America (Kritsky and Gutiérrez 1998, França et al. 2003, Cohen and Kohn 2008, Mendoza-Franco and Scholz 2009, Cepeda and Luque 2010, Monteiro et al. 2010). The major numbers of species were reported from Brazilian waters, a total of 11 species found in 7 hosts species. In Argentina 10 species have been reported in Río de La Plata, Río Uruguay, and Río Salado (Santa Fe) from six fishes species of families Pimelodidae, Heptapteridae, Loricariidae and Auchenipteridae.

Samborombón Bay is located in the south-western region of the Río de La Plata estuary, between Punta Piedras $\left(32^{\circ} 57^{\prime} \mathrm{S}, 57^{\circ} 08^{\prime} \mathrm{W}\right)$ and Punta Rasa $\left(36^{\circ} 18^{\prime} \mathrm{S}, 56^{\circ} 48^{\prime} \mathrm{W}\right)$, on the northeast coast of Buenos Aires Province. This area encompasses Argentina's most extensive mixohaline wetland. During a study of parasites of Parapimelodus valenciennis from this area, a new species of Demidospermus Suriano, 1983 was collected. In this paper the new species is described and illustrated.

\section{Materials and methods}

Specimens of $P$. valenciennis were collected using cast nets between 2006 and 2008 from the Salado River, the main river entering Samborombón Bay. Live fish were transported to the laboratory in containers filled with estuarine water and held in oxygenated aquaria prior to their examination. A total of 118 fish, ranging in total length from 5.9 to $22.3 \mathrm{~cm}$, were examined for parasites. Excised gills from freshly killed fishes were examined under a dissecting microscope, and monogeneans were collected, heat-fixed without pressure, preserved in $10 \%$ formalin and mounted in glycerine-jelly for study. In order to study details of their internal anatomy, 25 specimens of monogeneans were heat-fixed under pressure, preserved in $10 \%$ formalin, then stained with Van Cleave's haematoxylin, passed through a series of increasing ethanol concentrations between 70 and $100 \%$, cleared in clove oil and mounted in Canada balsam. Other specimens were stained using Gomori's stain for studying the sclerotized hard-parts.

Measurements and drawings were made using a Nikon Optiphot-2 microscope with DIC optics at magnifications of $\times 400$ and $\times 1,000$ and a Wild M20 microscope at a magnifica- 

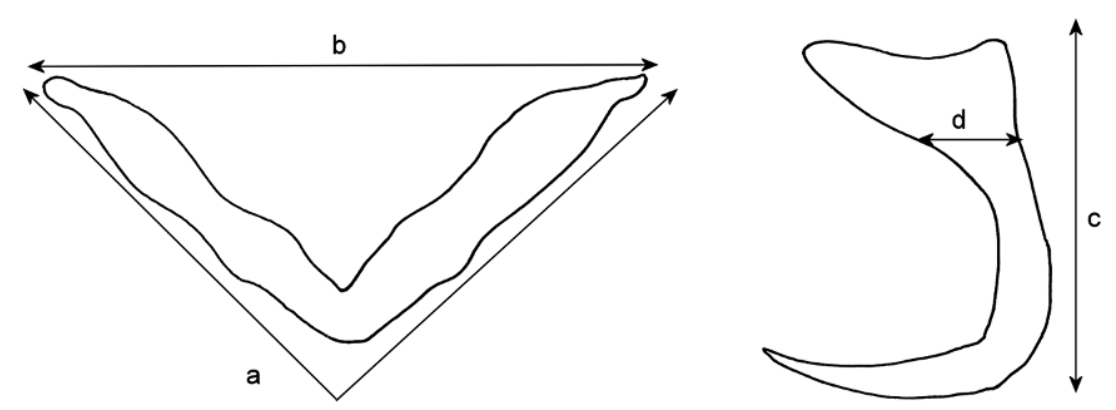

Fig. 1. Scheme of measurements for the anchors and bars: $\mathbf{a}$ - bar length, $\mathbf{b}$ - bar distance between ends, $\mathbf{c}-$ anchor length, $\mathbf{d}-$ anchor base width

tion of $\times 1,500$ for the sclerotized hard-parts and internal organs. Figures were prepared with the aid of a drawing apparatus. Microphotographs of the sclerotized structures were taken using DIC optics on an Olympus BX51 microscope with an Olympus digital camera. The measuring scheme of anchors and bar is presented in Figure 1. Measurements are given in micrometres as the mean with the range in parentheses. Numbering (distribution) of hooklets pairs following Mizelle (1963) for adult dactylogyrids.

The following abbreviations are used throughout the text: APL, accessory piece length; BL, body length; BW, body width; DABW, dorsal anchor base width; DAL, dorsal anchor
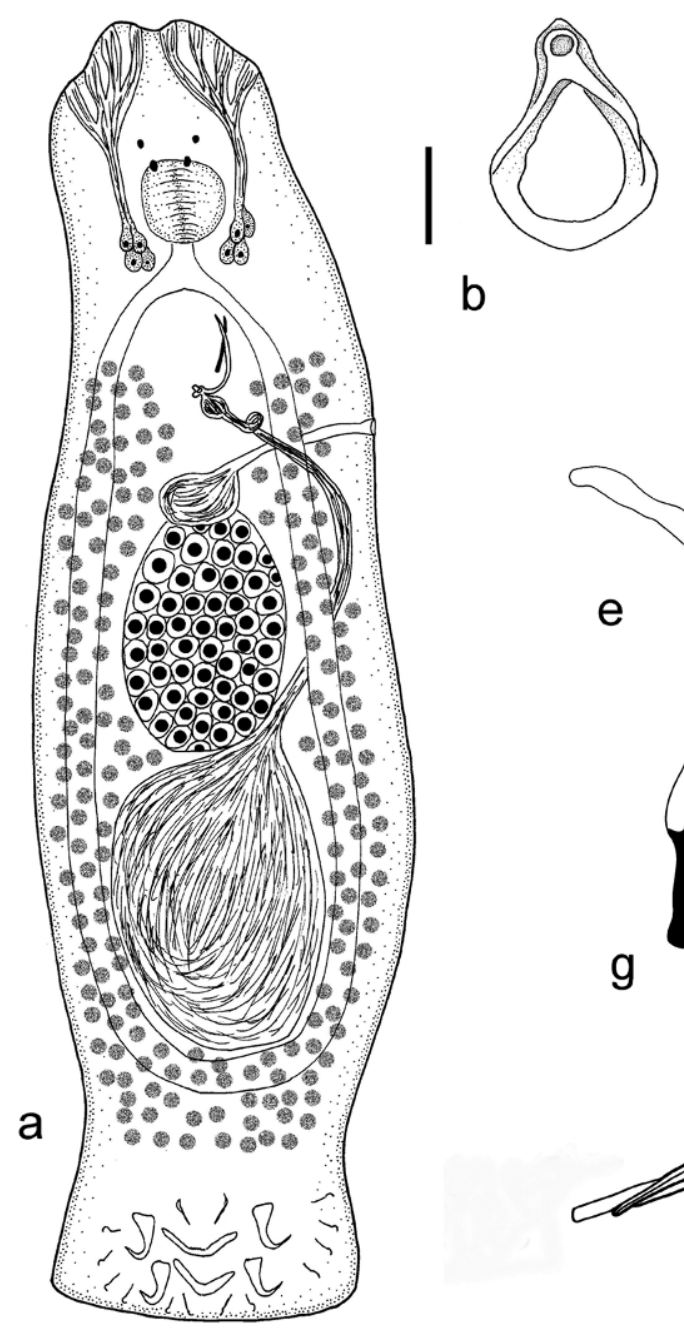

b
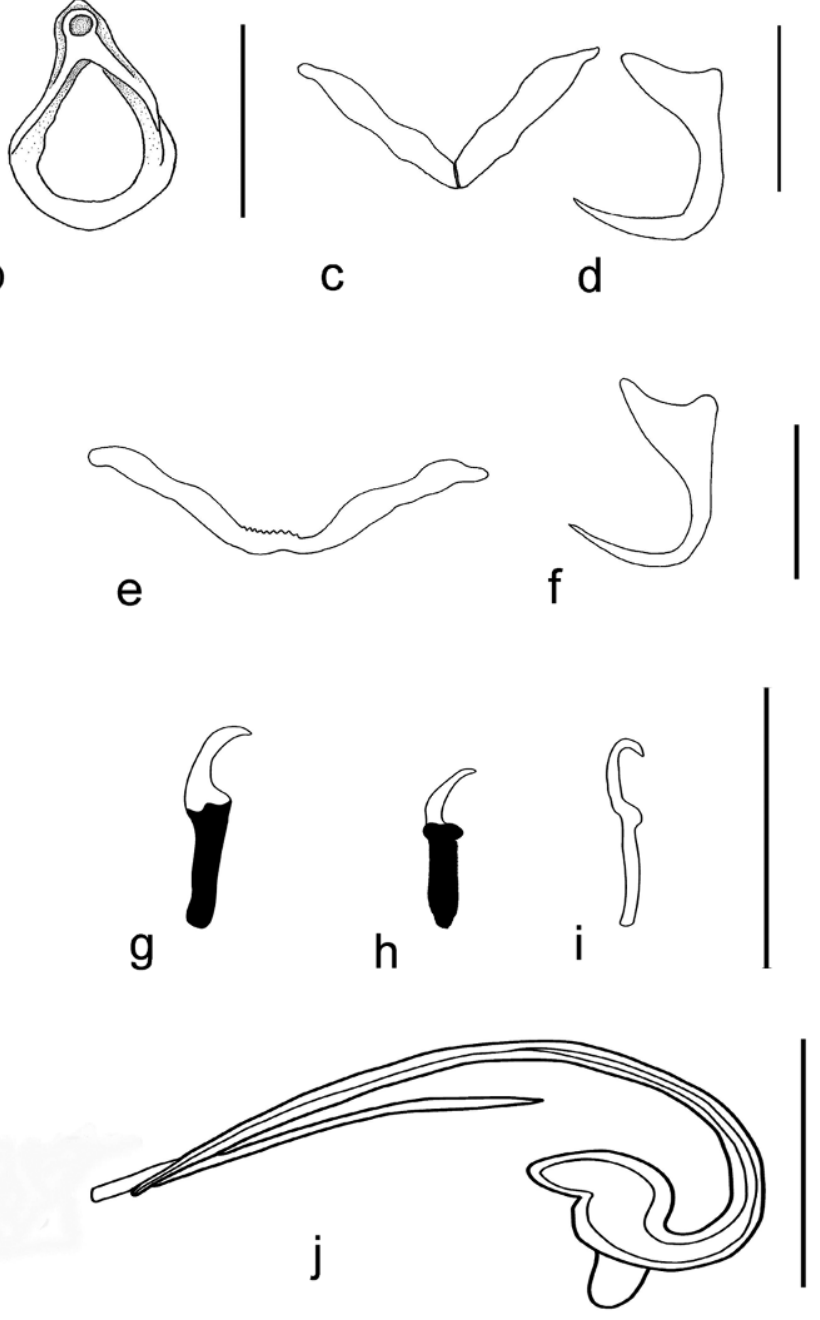

Fig 2. Demidospermus annulus sp. nov.: a - entire worm, ventral view; $\mathbf{b}$ - sclerotized vagina; $\mathbf{c}$ - dorsal bar; $\mathbf{d}$ - dorsal anchor; e - ventral bar; $\mathbf{f}$ - ventral anchor; $\mathbf{g}$ - hook pair I; $\mathbf{h}$ - hook pair VII; $\mathbf{i}$ - hook pairs II-VI; $\mathbf{j}$ - male copulatory organ, tube and accessory piece. Scale bars $=20 \mu \mathrm{m}(\mathrm{a}, \mathrm{c}-\mathrm{f}), 25 \mu \mathrm{m}(\mathrm{b}, \mathrm{g}-\mathrm{i}), 20 \mu \mathrm{m}(\mathrm{j})$ 


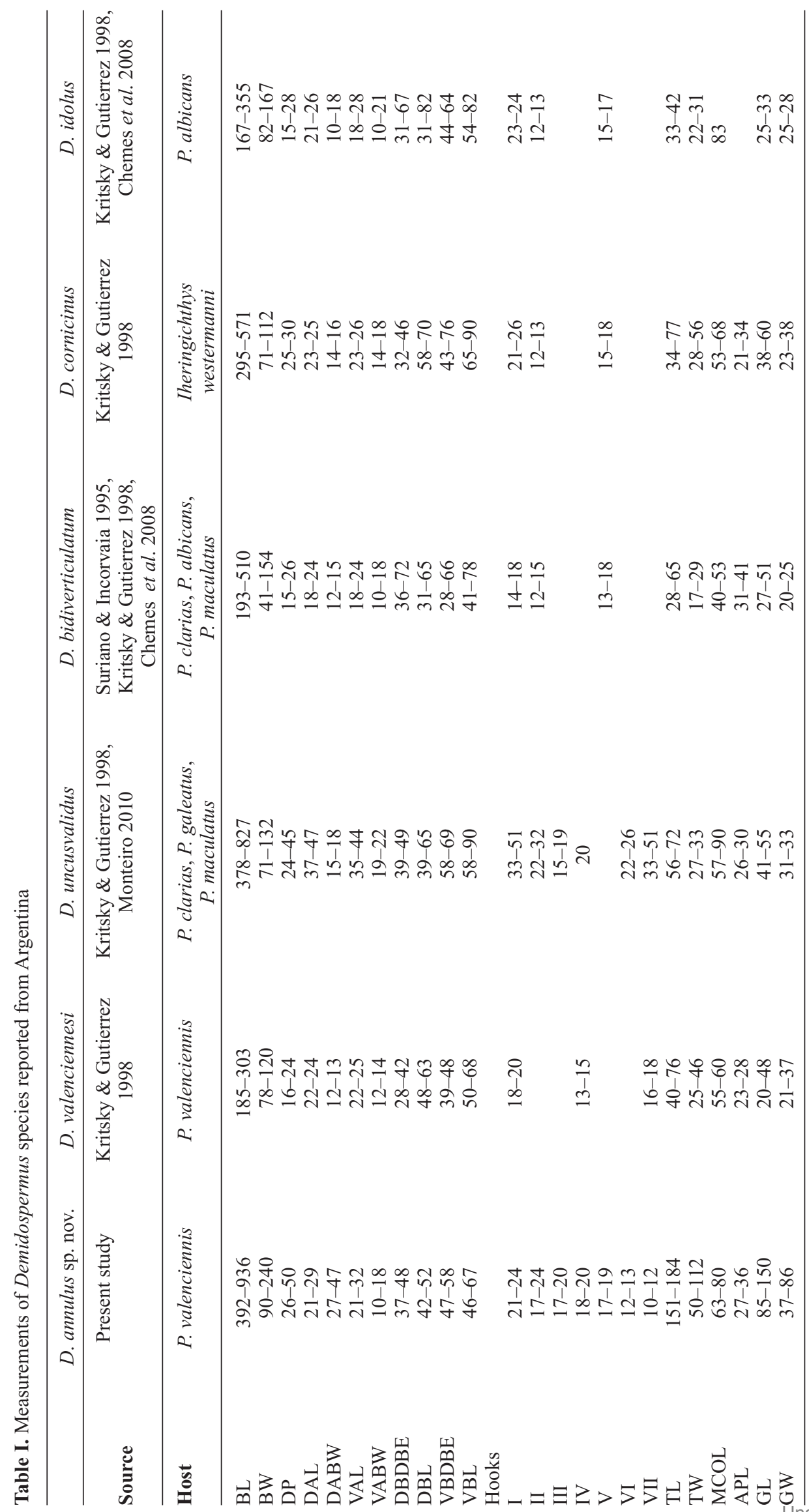




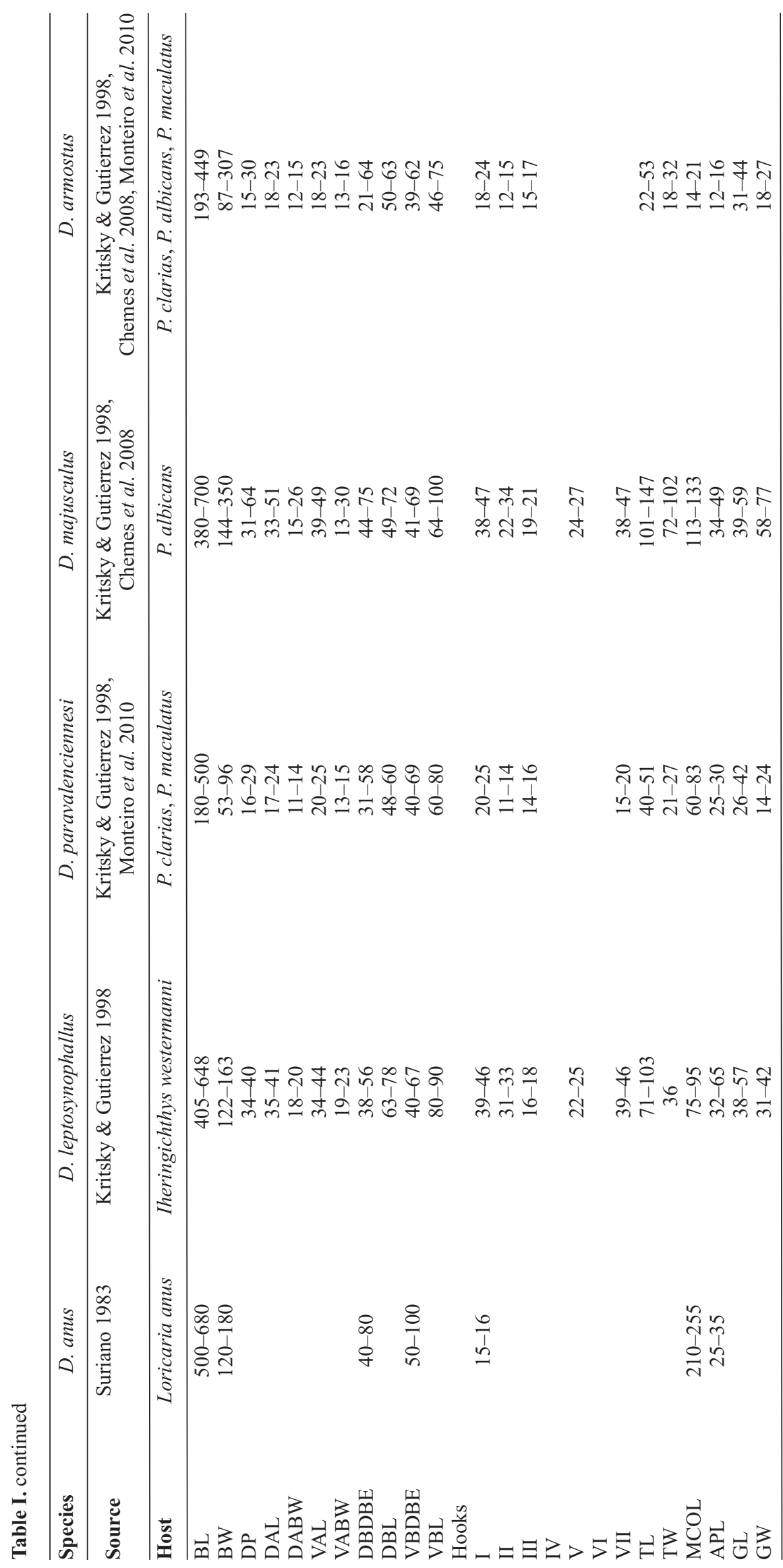


length; DBDBE, dorsal bar distance between ends; DBL, dorsal bar length; DP, diameter of pharynx; GL, germarium length; GW, germarium width; $\mathrm{MCO}$, male copulatory organ; MCOL, MCO length; VABW ventral anchor base width; VAL, ventral anchor length; VBDBE, ventral bar distance between ends; VBL, ventral bar length; TL, testes length; TW, testes width.

Demidospermus annulus sp. nov. (Fig. 2, Table I)

Description. Body 620 (392-936) long, fusiform, maximum width $156(90-240)$ at level of gonads. Two terminal, and 2 bilateral, cephalic lobes. Four eye-spots. Pharynx subspherical, 41 (26-50) in diameter. Testes ovoid, 168 (151-184) long, 81 (50-112) width. MCO J-shaped, 70 (63-80) long. Accessory piece 30 (27-36) long, straight to slightly curved, rod-shaped, only distal end in contact with MCO. Vas deferens looping left intestinal caecum. Vaginal aperture sinistral, sclerotized ringshaped, leading to seminal receptacle. Germarium ovoid, 117 (85-150) long, 56 (37-86) wide. Vitellaria scattered throughout trunk. Similar anchors, short shaft, elongated point, roots poorly defined. Ventral anchor 28 (21-32) long, base 15 (1018). Dorsal anchor 26 (21-29) long, base 15 (10-28). Ventral bar slightly V- or U-shaped 59 (46-67) long, distance between ends 54 (47-58). Dorsal bar V-shaped with articulation, 47 (42-52) long, distance between ends 43 (37-48). Hooks dissimilar in size, each with recurved point, pair I 22 (21-24) long, pairs II, III, IV, V 18 (17-22) long, pair VI 13 (12-15) long, pair VII 11 (10-12) long.

Type host: Parapimelodus valenciennis (Lütken, 1874).

Site of infection: Gill lamellae.

Type locality: Samborombón Bay $\left(32^{\circ} 57^{\prime} \mathrm{S}, 57^{\circ} 08^{\prime} \mathrm{W}\right)$, Buenos Aires, Argentina.

Specimens deposited: Deposited in the Museo de la Plata, Invertebrates Collection. La Plata, Argentina. Holotype No. MLP 6302, paratypes No. MLP 6303.

Etymology: The specific name is from Latin (annulus $=$ ring) and refers to the ring-shaped sclerotized vaginal aperture.

\section{Remarks}

The features of specimens analyzed here agree with the genus Demidospermus Suriano, 1983 and the emended diagnosis provided by Kritsky and Gutiérrez (1998). Demidospermus species can be readily distinguished from other species of the genus by the morphology of the MCO, the ring shaped vaginal sclerite, and measurements of the sclerotized parts of the haptor.

Demidospermus valenciennesi Gutiérrez et Suriano, 1992 has been previously reported on Parapimelodus valenciennis from Río de La Plata, Buenos Aires, Argentina. The new species can be distinguished from $D$. valenciennesi by the greater distance between the ends of the dorsal bar and distal ends of the ventral bar, and by the bigger measurement of: hooks (I and II), testes, germarium, MCO, and accessory piece of MCO (see Table). Additionally, the MCO accessory piece of $D$. valenciennesi is sheath-like instead of rod-shaped in the new species, the dorsal bar has an articulation in the new species, and by the morphology of vaginal sclerite that is clearly different in the new species compared with $D$. valenciennesi.

Currently, nine species of Demidospermus have been reported from the Río de La Plata, D. anus Suriano, 1983 from Loricariichthys anus, D. paravalenciennesi Gutiérrez et Suriano, 1992, D. bidiverticulatum Suriano et Incorvaia, 1995, and D. armostus Kritsky et Gutiérrez, 1998 from Pimelodus maculatus, D. cornicinus Kritsky et Gutiérrez, 1998 and D. leptosynophallus Kritsky et Gutiérrez, 1998 from Bergiaria westermanii, D. idolus Kritsky et Gutiérrez, 1998 and D. majusculus Kritsky et Gutiérrez, 1998 from P. albicans, and D. uncusvalidus Gutiérrez et Suriano, 1992 from P. maculatus and Trachelyopterus galeatus. The new species differs from all these species by the morphology of the MCO, by the measurements of haptoral pieces, and by the size of the testes and germarium (Table I).

Conversely, D. annulus sp. nov. resembles $D$. cecarrelli Cepeda et Luque, 2010 by the J-shaped MCO. However, the new species can be distinguished from $D$. ceccarelli by the morphology of accessory piece of MCO.

In summary, D. annulus sp. nov. differs from all congeneric species by the structure of the MCO accessory piece, the sclerotized ring-shaped vaginal aperture and the dorsal bar articulation.

Acknowledgements. This work was funded by a fellowship grant from Consejo Nacional de Investigaciones Científicas y Tecnológicas (CONICET) and UNLP to the authors.

\section{References}

Cepeda P., Luque J. 2010. Three new species of Demidospermus (Monogenea: Dactylogyridae) parasitic on Brachyplatystoma filamentosum (Siluriformes: Pimelodidae) from the Araguaia River, Brazil. Journal of Parasitology, 96, 869-873. DOI: 10.1645/GE-2331.1.

Chemes B., Takemoto R., Sottini R. 2008. Comunidad de Monogenea en las branquias de Pimelodus albicans (Valenciennes, 1840) en el río Salado del Norte, San Justo (Santa Fe, Argentina). Parasitologia Latinoamericana, 63, 51-57.

Cohen S.C., Kohn A. 2008. South American Monogenea - list of species, hosts and geographical distribution from 1997 to 2008. Zootaxa, 1924, 1-42.

França J.G., Isaac A., Pavanelli G.C., Takemoto R.M. 2003. Dactylogyridae (Monogenea) from the gills of Iheringicthys labrosus (Osteichthyes: Pimelodidae) from the upper Paraná river floodplain, Brazil, with the proposal of Pseudovancleaveus n.g. Systematic Parasitology, 54, 25-31. DOI: 10.1023/A:1022 113626634.

Gutiérrez P.A., Suriano D.M. 1992. Ancyrocephalids of the genus Demidospermus Suriano, 1983 (Monogenea) parasites from siluriform fishes in Argentina, with descriptions of three new species. Acta Parasitologica, 37, 169-172. 
Kritsky D.C., Gutiérrez P.A. 1998. Neotropical Monogenoidea. 34 Species of Demidospermus (Dactylogyridae, Ancyrocephalinae) from the gills of pimelodids (Teleostei, Siluriformes) in Argentina. Journal of the Helminthological Society of Washington, 65, 147-159.

Mendoza-Franco E., Scholz T. 2009. New dactylogyrids (Monogenea) parasitizing the gills of catfishes (Siluriformes) from the Amazon River Basin in Peru. Journal of Parasitology, 95, 865-870. DOI: 10.1645/GE-1820.1.

Mizelle J. 1963. New species of trematodes from gills of Illinois fishes. American Midland Naturalist, 17, 785-1029.

Monteiro C., Kritsky D., Brasil-Sato M. 2010. Neotropical Monogenoidea. 55. Dactylogyrids parasitising the pintado-amarelo
Pimelodus maculatus Lacépède (Actinopterygii: Pimelodidae) from the Rio Sao Francisco, Brazil. Systematic Parasitology, 76, 179-190. DOI: 10.1007/s11230-010-9250-2.

Suriano D.M. 1983. Demidospermus anus gen. nov. sp. nov. (Monogenea: Ancyrocephalinae) parasito branquial de Loricaria anus Valenciennes, 1840 (Pisces: Loricariidae) de la laguna de Chascomus, provincia de Buenos Aires, Republica Argentina. Neotropica, 29, 111-119.

Suriano D.M., Incorvaia I.S. 1995. Ancyrocephalid (Monogenea) parasites from siluriform fishes from the Paranean-Platean ichthyogeographical province in Argentina. Acta Parasitologica, 40, 113-124.

(Accepted February 16, 2011) 